\title{
IMPLEMENTATION OF CSR PROGRAMS TOWARD ACHIEVEMENT OF THE SDGs TARGET
}

\author{
Weni Apriliyani ${ }^{1}$, Novita $^{1}$ \\ ${ }^{1}$ Akuntansi, Fakultas Ekonomi dan Bisnis, Universitas Trilogi \\ Email: weniapriliyani@gmail.com \\ Email: novita1210@trilogi.ac.id
}

\begin{tabular}{l} 
INFO ARTIKEL \\
\hline Histori Artikel : \\
Tgl. Masuk : 15 \\
Februari 2019 \\
Tgl. Diterima : 01 Maret \\
2019 \\
Tersedia Online : 29 Maret \\
2019
\end{tabular}

Keywords:

CSR, SDG's Target, GRI-

Standards
ABSTRAK/ABSTRACK

Preparation of this study aimed to evaluate whether CSR program PT Holcim Indonesia Tbk has met the criteria of GRI-Standard and determine whether CSR program PT Holcim Indonesia Tbk is able to support perncapaian SDG's targets in 2030. This study is a qualitative and quantitative research. Research data collection techniques by interviewing the management of PT Holcim Indonesia Tbk namely Community Relations division and the local government. The second data collection techniques is by distributing questionnaires to people who get Holcim CSR program. The results of data analysis in this research produces information that only PT Holcim Indonesia CSR program Tbk economics that has influence on the target perncapaian SDG's. While the social and environmental fields have not been proven to have an effect on the achievement of the target SDG's. The results of the data analysis was due largely Holcim CSR program is only focused on the achievement of the economy and the realization of all the indicators for the achievement of SDG's may have been performed by the company as a whole, but does't plan implemented CSR programs on community sustainability.

$\begin{array}{lcc}\text { lingkungan, } & \text { sehingga nantinya } & \text { dapat } \\ \text { mengancam } & \text { keberlangsungan } & \text { hidup } \\ \text { perusahaan. } & \text { Kelangsungan } & \text { hidup }\end{array}$
perusahaan selalu dihubungkan dengan kemampuan manajemen dalam mengelola perusahaan agar dapat memper-tahankan hidup perusahaan. Manajemen perusahaan dapat mempertahankan hidup perusahaan jika tiga unsur keuntungan, kelestarian lingkungan dan kesejahteraan masyarakat sekitar dapat diseimbangkan dalam setiap kegiatan operasional peru-sahaan. konsep triple buttom line yang mengimplikasikan bahwa perusahaan harus lebih mengutamakan kepentingan stake-holder (semua pihak yang terlibat dan terke-na dampak dari kegiatan yang dilakukan perusahaan) dibandingkan kepentingan shareholder (pemegang saham). Triple bottom line dikenal dengan istilah "Formula 3P", yaitu terdiri dari unsur people (perusahaan yang mempedulikan sosial dan lingkungan disekitarnya), profit (perusahaan berupaya meningkatkan keuntungan bagi perusahaan), dan planet (kemampuan 
perusahaan dalam menjaga kelestarian alam/bumi) (Wibosono, 2007).

Setiap unsur pada teori triple buttom line memiliki peran yang penting untuk pemenuhan tanggungjawab perusahaan. Unsur people dan planet merupakan pemenuhan tanggungjawab perusahaan pada pihak eksternal (stakeholder dan shareholder), sedangkan profit pemenuhan tanggungjawab perusahaan dari pihak internal (manajemen). Pemenuhan tanggungjawab perusahaan tersebut bermuara pada program corporate social responsibility. Berjalannya program CSR di Indonesia awalnya hanya sebatas bantuan sosial karena adanya bencana alam, pembagian tunjangan hari raya, dan beasiswa. Namun seiring berjalannya waktu pemerintah menghimbau bahwa yang perlu diperhatikan perusahaan bukan hanya shareholder saja namun pegawai, masyarakat, lingkungan, media masa, dan pemerintah juga harus diperhatikan. Namun karena pada saat itu belum ada peraturan dan ketenuan yang mengatur resmi sehingga berita tersebut hanya dijadikan sebagai isue dan himbauan belaka. Hal tersebut menjadi bahan evaluasi pemerintah untuk membuat suatu legalitas hukum yang mengatur tentang kewajiban perseroan, hasil evaluasi pemerintah tersebut menghasilkan regulasi yaitu Undangundang No 40 yang mengatur tentang kewajiban perseroan terbatas. Dalam Undang-undang No 40 Tahun 2007 Bab $\mathrm{V}$ Pasal 74 ayat 1 menyatakan bahwa suatu instansi yang berbentuk perseroan dan jika perseroan tersebut kegiatan usahanya berkaitan dengan sumber daya alam makan harus bertanggung jawab secara sosial dan lingkungan.

Regulasi yang mengatur tentang implementasi corporate social responsibility bukan hanya Undangundang No 40 Tahun 2007, namun global reporting initiative (GRI) juga menerbitkan standar untuk perusahaan dalam menyusun kerangka kerja untuk membuat laporan berkelanjutan yang dapat diadopsi oleh semua jenis organisasi di semua negara. Terbitnya GRI-Standards dapat berdampak positif terhadap tujuan pembangunan berkelanjutan. Dampak yang ditimbulkan dari adanya GRI
Standards akan menunjang dan mempermudah tercapainya tujuan pembangunan berke-lanjutan secara global (SDG's). Tanpa kemiskinan, kelaparan, kesehatan yang baik, pendidikan berkualitas, kesetaraan gender, air bersih, terjangkaunya energi, pekerjaan layak, infrastruktur, mengurangi kesenjangan, keberlanjutan kota, tanggung-jawab produksi, aksi iklim, kehidupan bawah laut, darat, kedamaian, dan kemitraan. Tuju-an pembangunan berkelanjutan tersebut jika secara keseluruhan tercapai sampai tahun 2030 dapat tercermin bahwa kehidupan dunia sejahtera dan mencapai kualitas hidup yang baik pada setiap individu dimuka bumi. SDG's tersebut merupakan agenda dunia dalam pembangunan untuk mencapai kemaslahatan manusia, kelestarian lingkungan, dan melindungi ekosistem fauna.

Kemaslahatan manusia di bumi dapat dicapai apabila setiap masyarakat dapat diberdayakan dengan baik. Pemberdayaan masyarakat pada dasarnya merupakan proses untuk membuat masyarakat menjadi berdaya. Setiap anggota masyarakat dalam sebuah komunitas sebenarnya memiliki potensi, gagasan serta kemampuan untuk membawa dirinya dan komunitasnya untuk menuju ke arah yang lebih baik, namun potensi itu terkadang tidak bisa berkembang disebabkan faktor-faktor tertentu. Proses penyadaran masyarakat tersebut dilakukan melalui konsep-konsep pengembangan kapasitas. Pengembangan kapasitas masyarakat merupakan upaya pengembangan pengetahuan, sikap dan keterampilan masyarakat agar dapat berperan serta aktif dalam menjalankan pembangunan secara mandiri dan berkelanjutan. Sehingga seringkali para peneliti ingin membuktikan teori-teori tersebut dengan melakukan penelitian.

Salah satunya adalah Farida (2014) dalam penelitian (Haryono., et.al, 2018) menunjukan bahwa program corporate social responsibility berpengaruh terhadap kesejahteraan masyarakat di BMT harapan umat kudus pada penelitian-nya yang berjudul implementasi program corporate social responsibility. Hal tersebut membuktikan bahwa masyarakat dapat diberdayakan atas program-program CSR yang dijalankan dan dipertanggungjawabkan perusahaan pada lingkungan dan masyarakat. Bahkan bukan hanya Farida 
yang menyatakan hal tersebutternyata (Mapisangka, 2009) juga melakukan penelitian mengenai implementasi CSR PT Batamindo Investment Cakrawala terhadap kesejahteraan masyarakat, hasil penelitian Mapisangka sama dengan hasil penelitian Farida yang menyarakan bahwa corporate social responsibility goal PT.BIC dapat memberikan pengaruh terhadap peningkatan kesejahteraan hidup masyarakat Batam. Namun peningkatan kesejahteraan hidup masyarakat tersebut tidak sepenuhnya berpengaruh positif terhadap pemberdayaan masyarakat karena program $C S R$ hal tersebut telah dibuktikan pada penelitian dilakukan oleh (Dwijatenaya, 2017) dengan judul penelitian Corporate Social Responsibility (CSR): Empowering Program For Farmers Welfare. Dengan hasil penelitian tersebut menyatakan bahwa masyarakat yang diberdayakan sudah pasti hidupnya dalam keadaan yang sejahtera, namun jika masyarakat tersebut telah sejahtera maka belum tentu mereka diberdayakan, karena kesejahteraan masyarakat dapat direalisasikan dengan memberikan bantuan sesuai dengan kebutuhan masyarakat tanpa memberikan kegiatan yang membuat setiap masyarakat tersebut diberdayakan.

Salah satu program CSR Holcim yang telah terbukti meningkatkan kesejahteraan masyarakat dengan meningkatkan kemandirian ekonomi masyarakat dan meningkatkan kepengurusan suatu organisasi. Program CSR PT Holcim Indonesia Tbk tersebut adalah Posdaya. Pada penelitian (Novita \& Iriani, 2016) menyatakan bahwa PT Holcim Indonesia Tbk sudah melakukan kegiatan tanggungjawab social (CSR) kepada masyarakat, kegiatan yang dilaksanakan pada program CSR merupakan program yang diajukan masyarakat sesuai dengan kebutuhannya. Sehingga manajemen Holcim hanya mengkaji, menyetujui, dan mendanai kegiatan tersebut. Sehingga dengan adanya program tersebut masyarakat mampu mengembangkan keahliannya dan mampu meningkatkan kemampuan perekonomian. Pemberian modal pada umkm merupakan salah satu bentuk program CSR yang mampu meningkatkan kesejahteraan masyarakat tanpa memberdayakan masyarakat.
Dengan adanya pemberian modal tersebut akan membantu kendala keuangan yang terjadi pada umkm, tanpa memberikan arahan dan pelatihan sehingga umkm tersebut tidak diberdayakan atas bantuan financial tersebut. Posdaya merupakan salah satu program CSR yang mampu memberdayakan masyarakat, karena posdaya memberikan wawasan dan mengasah kemampuan masyarakat untuk mengelola sumber-sumber daya untuk menghasilkan produk olahan yang memiliki nilai jual. Jika kegiatan tersebut terimplementasi dengan baik maka dapat dikatakan bahwa masyarakat telah diberdayakan dengan adanya program CSR tersebut. Bahkan bukan hanya diberdayakan saja, tujuan pembangunan berkelanjutan (SDG's) diharapkan dapat direalisasikan dengan adanya program CSR tersebut.

Namun salah satu peneliti telah membuktikan dalam penelitiannya bahwa program $C S R$ yang dijalankan perusahaan pada lingkungan dan masyarakat secara garis besar telah memenuhi SDG's target namun tidak secara keseluruhan, program CSR tersebut hanya secara dominan memenuhi aspek sosial pada SDG's target (Theresia, 2018). Sehingga penelitian ini tertarik untuk mengkaji salah satu perseroan yang memiliki berbagai macam program CSR dan selalu mendapatkan penghargaan karena program CSRnya. Perseroan tersebut adalah PT Holcim Indonesia Tbk.

PT Holcim Indonesia Tbk merupakan salah satu industri produsen semen terbesar di Indonesia. Holcim Indonesia memiliki tiga pabrik semen masing-masing di Narogong, Cilacap, dan Tuban dengan total kapasitas maksimum 12.5 juta ton semen per tahun. PT Holcim Indonesia Tbk Cilacap menjalankan program CSRnya berlatar belakang karena dalam kegiatan industrinya perseroan tersebut sumber bahan baku semennya diambil dari Pulau Nusa Kambangan yang berada di Kabupaten Cilacap. Sehingga perseroan tersebut harus mepertanggung jawabkan segala dampak dan risiko yang timbul karena kegiatan industrinya. Lingkungan Kabupaten Cilacap yang nyaman, bersih dan tertata dengan rapih merupakan salah satu dampak yang dihasilkan karena adanya program CSR PT Holcim Indonesia Tbk dan juga program CSR PT Holcim Indonesia Tbk berdampak 
pada kehidupan masyarakat Kabupaten Cilacap yang dapat mengolah hasil bumi untuk dijadikan sebagai alternatif mata pencarian saat laut dalam keadaan ombak besar dan menyebabkan tidak dapat bernelayan.

Dampak dari adanya program CSR yang dijalankan PT Holcim Indonesia Tbk tersebut memang sudah secara langsung dirasakan oleh masyarakat Kabupaten cilacap dan telah mampu merubah pola hidup masyarakat sehingga memperbaikin kehidupan masyarakat Cilacap, namun belum dapat dibuktikan secara pasti mengenai program CSR yang telah dijalankan PT Holcim Indonesia Tbk tersebut telah membuat masyarakat merasa diberdayakan dan mampu mencapai SDG's sesuai dengan tiga unsur triple buttom line dan enam indikator GRI Standards. Berdasarkan uraian tersebut sehingga penelitian ini ingin mengkajian atas dampak implementasi program CSR PT Holcim IndonesiaTbk dan tercapainya SDG's target.

PT Holcim Indonesia Tbk merupakan salah satu industri produsen semen terbesar di Indonesia. Holcim Indonesia memiliki tiga pabrik semen masing-masing di Narogong, Cilacap, dan Tuban dengan total kapasitas maksimum 12.5 juta ton semen per tahun. PT Holcim Indonesia Tbk Cilacap menjalankan program CSRnya berlatar belakang karena dalam kegiatan industrinya perseroan tersebut sumber bahan baku semennya diambil dari Pulau Nusa Kambangan yang berada di Kabupaten Cilacap. Sehingga perseroan tersebut harus mepertanggung jawabkan segala dampak dan risiko yang timbul karena kegiatan industrinya. Lingkungan Kabupaten Cilacap yang nyaman, bersih dan tertata dengan rapih merupakan salah satu dampak yang dihasilkan karena adanya program CSR PT Holcim Indonesia Tbk dan juga program CSR PT Holcim Indonesia Tbk berdampak pada kehidupan masyarakat Kabupaten Cilacap yang dapat mengolah hasil bumi untuk dijadikan sebagai alternatif mata pencarian saat laut dalam keadaan ombak besar dan menyebabkan tidak dapat bernelayan.
Dampak dari adanya program CSR yang dijalankan PT Holcim Indonesia Tbk tersebut memang sudah secara langsung dirasakan oleh masya-rakat Kabupaten cilacap dan telah mampu merubah pola hidup masyarakat sehingga memperbaikin kehidupan mas-yarakat Cilacap, namun belum dapat dibuktikan secara pasti mengenai prog-ram CSR yang telah dijalankan PT Holcim Indonesia Tbk tersebut telah membuat masyarakat merasakan adanya program pemberdayaan yang bertujuan untuk mencapai SDG's sesuai dengan tiga unsur triple buttom line dan enam indikator GRI Standards. Berdasarkan uraian tersebut sehingga penelitian ini ingin mengkajian atas dampak implementasi program CSR PT Holcim IndonesiaTbk dan tercapainya SDG's target.

\section{KERANGKA TEORITIS DAN PENGEMBANGAN HIPOTESIS}

\section{Stakeholders Theory}

Konsep stakeholder merupakan konsep tanggung jawab sosial perusahaan yang secara umum dikenal dengan stakeholder theory artinya sebagai kumpulan kebijakan dan praktik yang berhubungan dengan stakeholder, nilai-nilai, pemenuhan ketentuan hukum, penghargaan masyarakat dan lingkungan, serta komitmen dunia usaha untuk berkontribusi dalam pembangunan secara berkelanjutan. Stakeholder theory dimulai dengan asumsi bahwa nilai secara eksplisit dan tak dipungkiri merupakan bagian dari kegiatan usaha (Freeman., et al 2004).

Teori stakeholder mengatakan bahwa perusahaan bukanlah entitas yang hanya beroperasi untuk kepentingannya sendiri, namun harus memberikan manfaat bagi stakeholder (pemegang saham, kreditor, konsumen, supplier, pemerintah, masyarakat, analis dan pihak lain). Dengan demikian, keberadaan suatu perusahaan sangat dipengaruhi oleh dukungan yang diberikan oleh stakeholder kepada perusahaan tersebut (Freeman, 2004).

\section{Tripel Buttom Line}

Menurut (Febrianto, 2014) pada teori yang dikenalkan oleh Elkington dalam bukunya yang berjudul Cannibals With Forks: The Triple Bottom Line in 21st Century Business. Elkington menganjurkan 
agar dunia usaha perlu mengukur sukses (atau kinerja) tak hanya dengan kinerja keuangan (berapa besar deviden atau bottom line yang dihasilkan), namun juga dengan pengaruh terhadap perekonomian secara luas, lingkungan dan masyarakat di mana mereka beroperasi. Disebut triple sebab konsep ini memasukkan tiga ukuran kinerja sekaligus: Economic, Environmental, Social (EES) atau istilah umumnya 3P: "Profit; Planet; People".

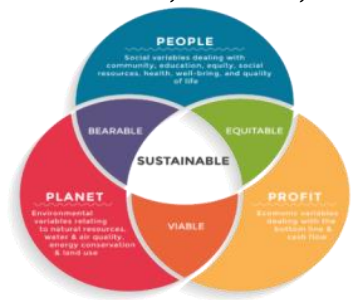

Gambar 1 Tripel Buttom Line Sumber: (Febrianto, 2014)

\section{Sustainibility Development Goals (SDGs)}

Sustainable Development Goals adalah sebuah kesepakatan pembangunan baru pengganti MDG's. Masa berlakunya 2015-2030 yang disepakati oleh lebih dari 190 negara, berisi 17 goals dengan tujuan umum mengatur tata cara dan prosedur yaitu masyarakat yang damai tanpa kekerasan, partisipasi, tata pemerintahan yang terbuka serta kerja sama kemitraan multi pihak. 17 tujuan dengan 169 sasaran diharapkan dapat menjawab ketertinggalan pembangunan negara-negara di seluruh dunia, baik di negara maju (konsumsi dan produksi yang berlebihan, serta ketimpangan) dan negara-negara berkembang (kemiskinan, kesehatan, pendidikan, perlindungan ekosistem laut dan hutan, perkotaan, sanitasi dan ketersediaan air minum).

Proses perumusan SDG's berbeda sekali dengan MDG's. SDG's disusun melalui proses yang partisipatif, salah satunya melalui survei myworld. Salah satu perubahan mendasar yang dibawa oleh SDG's adalah prinsip "tidak ada seorang pun yang ditinggalkan". SDG's juga mengandung prinsip yang menekankan kesetaraan antar negara dan antar warga negara. SDG's berlaku untuk semua negara-negara anggota PBB, baik negara maju, miskin, dan negara berkembang (PBB, 2017).

\section{CSR dan Target SDG'S}

Kemiskinan mempunyai dimensi yang kompleks. Kemiskinan tidak hanya bersinggungan dengan permasalahan ekonomi semata, tetapi juga berhubungan erat dengan berbagai dimensi kehidupan lainnya seperti politik, budaya maupun sosial. Demikian kompleksnya permasalahan kemiskinan menjadikan kemis-kinan sebagai permasalahan yang bersifat multidimensional. Kemiskinan diedfinisikan sebagai kekurangan penda-patan untuk memenuhi kebutuhan hidup yang pokok (BCCIndonesia, 2014). Pendapatan yang didapat tidak dapat memenuhi pangan, sandang, dan papan. Ditinjau dari sudut dimensinya, kemiskinan dapat dilihat sebagai akibat globalisasi, kemiskinan yang berkaitan dengan pembangunan, kemiskinan sosial, dan kemis-kinan.

Salah satu bentuk dari CSR adalah pengembangan masyarakat yang merupakan model dari pembangunan komunitas dengan tujuan untuk menjadikan komunitas menjadi mandiri dan berdaya. Pengembangan masya-rakat merupakan program yang disusun oleh perusahaan untuk meningkatkan partumbuhan ekonomi, keadaan lingkungan, pendi-dikan, keahlian, kesehatan, dan kesejahteraan dari stakeholder perusahaan, terutama bari mereka yang tinggal berdekatan atau dipe-ngaruhi oleh kegiatan perusahaan (Nigam,2009).

Kesejahteraan masyarakat dapat terealisasi saat kebutuhan material, spiritual, dan sosial setiap individu telah terpenuhi. Sehingga pemerintah berupaya untuk merealisasikan hal tersebut dengan dibuatkannya regulasi yang mengatur tentang tanggungjawab sosial perusahaan terhadap masyarakat. Tanggungjawab perusahaan tersebut merupakan suatu program sosial yang dirancang perusahaan, program sosial tersebut disebut dengan program corporate social responsibility. Sehingga banyak peneliti yang ingin membuktikan apakah terdapat hubungan program CSR terhadap peningkatan kesejahteraan masyarakat.

Salah satu penelitian yang telah menyatakan bahwa ada pengaruh signifikan antara CSR dan kesejahteraan masyarakat adalah (Farida, 2014) melakukan penelitian yang berjudul Analisis pengaruh implementasi CSR terhadap kesejahteraan sosial di BMT harapan umat kudus. Hasil pene- 
litian tersebut sama dengan hasil penelitian yang dilakukan oleh Mapisangka pada tahun 2009 dan penelitian Haryono, Mahsuni, Junaidi tahun 2018mengenai implementasi CSR PT Batamindo Investment Cakrawala terhadap kesejahteraan masyarakat. Pene-litian ini dilakukan tujuannya untuk menge-tahui hubungan corporate social respon-sibility goal, corporate social issues, dan cor-porate relation program terhadap kesejah-teraan masyarakat. Berdasarkan pada hasil analisis data yang dilakukan pada penelitian ini memberikan hasil bahwa corporate social responsibility goal, corporate social issues, dan corporate relation program PT.BIC dapat memberikan pengaruh terhadap peningkatan kesejahteraan hidup masyarakat Batam dan pada penelitian Haryono, dkk menyatakan hal sama yang terealisasi pada masyarakat Desa Bimo, Kecamatan Probolinggo. Ternayata bukan hanya CSR Goal saja yang akan mempengaruhi kesejahteraan masyarakat seperti yang dihasilkan pada penelitian (Mapisangka, 2009) namun CSI dan CRP dalam penelitian Setyaningrum (2011) secara segnifikan berpengaruh positif terhadap kesejahteraan masyarakat.

Kesejahteraan masyarakat tersebut dapat terjadi jika kemampuan perekonomian masyarakat memadai. Salah satu perusahaan yang telah memberikan perbaikan kemam-puan ekonomi pada masyarakat adalah PT Holcim Indonesia Tbk. Sesuai dengan penelitian (Novita \& Iriani, 2016) yang menyatakan bahwa karena adanya Posdaya sebagai salah satu program CSR Holcim mampu meningkatkan kemandirian ekonomi masyarakat dengan memberikan kegiatan-kegiatan yang mampu meningkatkan keahlian masyarakat. Dengan meningkatkan keahlian masyarakat tersebut mampu menghasilkan produk yang dapat dijual dan mendapatkan penghasilan. Sehingga mampu meningkatkan kesejahteraan masyarakat pada bidang ekonomi.

Bahkan bukan hanya
kesejahteraan masyarakat namun $C S R$ juga dapat berpe-ngaruh terhadap pemberdayaan masyarakat. Hal tersebut dapat terjadi karena dapat tercermin pada nyatanya program $C S R$ perusahaan memiliki dampak yang luas untuk masyarakat dan akan memberikan pengaruh positif pada kehidupan masyarakat. Pene-litian tersebut dilakukan oleh (Dwija-tenaya, 2017) dengan judul penelitian Corporate Social Responsibility (CSR): Empowering Program For Farmers Wel-fare. Ada beberapa kesimpulan penting yang bisa ditarik pada hasil pembahasan penelitian, yaitu efek CSR pada pemberdayaan yang positif dan signifikan. CSR memiliki efek positif dan signifikan terhadap lingkungan. Pember-dayaan memiliki efek positif dan signifikan terha-dap lingkungan. Efek pemberdayaan pada kesejahteraan tidak signifikan. Ling-kungan memiliki efek positif dan signifikan terhadap kesejahteraan.

Beberapa hasil penelitian yang telah dipaparkan sebelumnya secara keseluruhan menyatakan bahwa program CSR berpengaruh positif terhadap kesejahteraan masya-rakat dan pemberdayaan masyarakat. Namun kesejahteraan masyarakat dan pemberdayaan masyarakat tersebut belum menunjukan bahwa telah tercapainya target dari SDG's.

Sustainibility Development Goals memilik tujuhbelas target yang harus dipenuhi untuk mencapai kemaslahatan manusia. Sedangkan program CSR yang telah terimplementasi pada penelitian sebelumnya hanya berfokus pada beberapa target SDG's yaitu kemiskinan dan pendidikan berkualitas, untuk limabelas target lainnya belum menjadi komponen dari setiap program CSR yang dirancang oleh perusahaan. Teori tersebut dibuktikan dengan adanya penelitian yang menyatakan bahwa pengungkapan $C S R$ perusahaan apabila ditinjau dari tujuhbelas kriteria SDG's tampak masih perlu untuk dikembangkan. Hasil analisis menunjukan terdapat enam kriteria yang diungkapkan dari tujuhbelas kriteria oleh perusahaan yang tergabung pada IGCN. Pengungkapan yang dominan lebih ke arah sosial daripada lingkungan seperti: kesehatan dan kesejahteraan, pendidikan, air bersih dan sanitasi, konsumen dan kemitraan. Sehingga hasil penelitian ini dapat dijadikan pemetaan pengungkapan yang dominan dan kurang diungkapkan sehingga dapat meningkatkan motivasi pengungkapan CSR yang memenuhi kriteria SDG's (Theresia, 2018). 
Sehingga penelitian ini tertarik untuk membahas implementasi program CSR PT Holcim Indonesia Tbk terhadap pencapaian target SDG's. Perbedaan variabel penelitian ini dengan penelitian sebelumnya adalah sumber variabel dan pengembangan varia-bel penelitian. Dalam penelitian ini variabel penelitian bersumber dari index $G R I$ pada variabel independen (CSR), target SDG's pada variabel dependen. Berdasarkan tinjauan tersebut maka dalam penelitian ini menghasilkan pengembangan hipotesis yaitu :

$\mathrm{H} 1 \quad$ : Kegiatan CSR bidang ekonomi berpengaruh terhadap pencapaian target SDG's.

$\mathrm{H} 2$ : Kegiatan CSR bidang sosial berpengaruh terhadap pencapaian target SDG's.

H3 : Kegiatan CSR bidang lingkungan berpengaruh terhadap pencapaian target SDG's.

\section{METODOLOGI PENELITIAN}

Penelitian ini dilakukan di PT Holcim Indonesia Tbk yang berlokasi di Kabupaten Cilacap tepatnya berada di Jalan Ir H Juanda, Cilacap, Jawa Tengah, Indonesia. Waktu Penelitian dilaksanakan pada semester (tujuh) tahun ajaran 2019/2020. Target pengisian kuesioner penelitian ini adalah pemangku kepentingan PT Holcim Indonesia Tbk, masyarakat, masyarakat yang melaksanakan program CSR PT Holcim Indonesia. Alat ukur yang digunakan penelitian pada metode kuesioner adalah dengan menggunakan skala Likert.

\section{Variabel Penelitian}

\begin{tabular}{|l|l|}
\hline $\begin{array}{l}\text { Variabel } \\
\text { Independen }\end{array}$ & Indikator \\
\hline Ekonomi & Kinerja Ekonomi \\
\cline { 2 - 2 } & Keberadaan Pasar \\
\hline $\begin{array}{l}\text { Dampak Ekonomi Tidak } \\
\text { Langsung }\end{array}$ \\
\hline Lingkungan & Keanekaragaman Hayati \\
\hline & $\begin{array}{l}\text { Mekanisme pengaduan } \\
\text { masalah lingkungan }\end{array}$ \\
\hline & Energi \\
\hline & Air \\
\hline & Efluen dan Limbah \\
\hline
\end{tabular}

\begin{tabular}{|c|c|}
\hline $\begin{array}{l}\text { Variabel } \\
\text { Independen }\end{array}$ & Indikator \\
\hline & $\begin{array}{l}\text { Asesmen pemasok atas } \\
\text { lingkungan }\end{array}$ \\
\hline Sosial & \begin{tabular}{|l|} 
Kepegawaian \\
$\begin{array}{l}\text { Kesehatan dan Keselamatan } \\
\text { Kerja }\end{array}$ \\
Pelatihan dan Pendidikan \\
Kesetaraan Remunerasi \\
Perempuan dan Laki-laki \\
Hak adat \\
Pekerja anak \\
Asesmen \\
Masyarakat Lokal \\
Anti-Korupsi \\
Mekanisme Pengaduan \\
Dampak Terhadap Masyakat \\
\end{tabular} \\
\hline
\end{tabular}

\begin{tabular}{|c|c|}
\hline $\begin{array}{l}\text { Variabel } \\
\text { Dependend }\end{array}$ & Indikator \\
\hline \multirow[t]{16}{*}{ SDG's Targets } & Tanpa kemiskinan \\
\hline & Tanpa kelaparan \\
\hline & $\begin{array}{ll}\text { Pekerjaan layak dan } \\
\text { pertumbuhan ekonomi }\end{array}$ \\
\hline & $\begin{array}{lll}\begin{array}{l}\text { Kehidupan sehat dan } \\
\text { sejahtera }\end{array} & \text { dan } \\
\end{array}$ \\
\hline & Pendidikan berkualitas \\
\hline & Air bersih dan sanitasi layak \\
\hline & $\begin{array}{ll}\text { Energi } \\
\text { teriangkau }\end{array}$ \\
\hline & Berkurangnya kesenjangan \\
\hline & $\begin{array}{l}\text { Penanganan perubahan } \\
\text { iklim }\end{array}$ \\
\hline & Kesetaraan gender \\
\hline & $\begin{array}{l}\text { Konsumsi dan produksi } \\
\text { yang bertanggung jawab }\end{array}$ \\
\hline & $\begin{array}{l}\text { Ekosistem laut dan } \\
\text { Ekosistem daratan }\end{array}$ \\
\hline & $\begin{array}{l}\text { Perdamaian, keadilan dan } \\
\text { kelembagaan yang tangguh }\end{array}$ \\
\hline & $\begin{array}{l}\begin{array}{l}\text { Industri, inovasi dan } \\
\text { infrastruktur }\end{array} \\
\end{array}$ \\
\hline & $\begin{array}{l}\text { Kota dan komunitas } \\
\text { berkelanjutan }\end{array}$ \\
\hline & $\begin{array}{l}\text { Kemitraan untuk mencapai } \\
\text { tujuan }\end{array}$ \\
\hline
\end{tabular}

Sumber : GRI Standards (2018)

\section{Analisis data}

1. Analisis deskriptif

Statistika deskriptif ini merupakan metode-metode yang berkaitan dengan pengumpulan, peringkasan, dan penyajian 
suatu data sehingga memberikan informasi yang berguna, hal lain juga menatanya ke dalam bentuk yang siap untuk dianalisis. Dengan kata lain, statistika deskriptif ini merupakan fase yang membicarakan mengenai penjabaran dan penggambaran termasuk penyajian data. Dalam fase ini dibahas mengenai ukuran-ukuran statistik seperti ukuran pusat, ukuran sebaran, dan ukuran lokasi dari persebaran atau distribusi data. Dalam penjabaran dan penggambaran penyajian data harus disesuaikan dengan jenis data dan variabel berdasarkan skala pengukurannya (Hasan,2006).

\section{Analisis verifikatif}

Uji yang digunakan untuk menunjukkan sejauh mana alat ukur yang digunakan dalam suatu mengukur apa yang diukur. Ghozali (2009) menyatakan bahwa uji validitas digunakan untuk mengukur sah, atau valid tidaknya suatu kuesioner. Analisis verifikatif yang dilakukan dalam penelitian ini menggunakan aplikasi partial least square (PLS). Structural Equation Modeling (SEM) merupakan metode yang digunakan untuk membuat model struktural penelitian, karena metode ini tidak memerlukan asumsi dan dapat diestimasikan dengan sampel yang relatif kecil.

\section{HASIL DAN PEMBAHASAN}

\section{Analisa Model Struktural}

Teknik pengolahan data yang dilakukan dengan metode Partial Least Squere (PLS) versi 3.2.7 dengan indikator refleksi. Tahap-tahap analisis model struktural adalah sebagai berikut:

1. Analisis model measurement (outer model)

Model measurement ini mengukur hubungan antar variabel laten dengan setiap indikator pengukurannya atau mendefinisikan apakah setiap indikator pengukuran berkubungan dengan variabel latennya. Analisis outer model dilakukan untuk menguji validitas dan reliabilitas data. Uji yang dilakukan pada outer model dengan indikator refletif, sebagai berikut :

a. Uji Validitas
Uji validitas adalah suatu pengujian yang digunakan untuk melihat valid atau tidaknya suatu pernyataan pada setiap indikator. Untuk menguji validitas udah setiap pernyataan pada kuesioner terdapat dua uji yaitu validitas convergent dan validitas discriminant. Parameter pengujian untuk validitas convergent adalah loading factor, average variance extracted (AVE), dan communality. Sedangkan validitas discriminant adalah cross loading, akar kuadrat AVE dan korelasi antar konstruk laten.

\section{- Convergent validity}

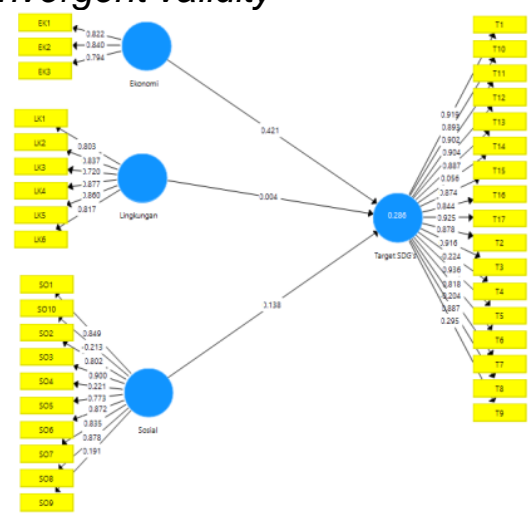

Gambar 2

Sumber: Pengolahan data kuesioner dengan SmartPLS versi 3.2.7, 2018

Convergent validity dalam model measurement dengan indikator reflektif dinilai berdasarkan hubungan antara item score yang diestimasi dengan menggunakan SmartPLS versi 3 . Nilai convergent validity dapat dilihat dari nilai loading factor pada variabel laten dengan indikator-indikatornya. Dengan korelasi nilai yang diharapkan yaitu lebih dari 0.70 (Ghozali, 2015). Jika nilai loading factor kurang dari 0.70 maka pernyataan tersebut tidak sesuai dengan indikator yang 
dinilainya. Hasil pengolahan menggunakan SmartPLS versi 3.2.7.

Nilai outers model atau korelasi antar konstruk dengan variabel pada awalnya belum memenuhi convergent validity karena terdapat beberapa indikator yang memiliki nilai outers model dibawah 0.70 indikator yang belum memnuhi batas nilai loading factor yang telah ditentukan yaitu SO4 dengan nilai 0.221 , SO9 dengan nilai 0.191 , SO10 dengan nilai -0.213 , T4 dengan nilai $0.224, \mathrm{~T} 7$ dengan nilai -0.204 , T9 dengan nilai 0.295 , dan T14 dengan nilai 0.056 . Terdapat tujuh indikator yang belum memenuhi kriteria convergent validity, sehingga total indikator yang telah memenuhi kriteria convergent validity adalah 29 indikator.

Dapat disimpulkan bahwa pernyataan yang terdapat pada setiap indikator tersebut tidak valid. Sehingga pernyataan tersebut tidak dapat digunakan untuk menilai indikatornya. Pernyataan yang menyatakan bahwa perusahaan rutin memberikan pelatihan keterampilan untuk meningkatkan kompetensi masyarakat tidak valid untuk menjawan indikator SO4 yaitu kesetaraan remunerasi laki-laki dan perempuan. Dan seterusnya untuk indikator anti korupsi, mekanisme pengaduan dampak terhadap masyarakat, kehidupan sehat dan sejahtera, energi bersih dan terjangkau, penanganan perubahan iklim, dan industri, inovasi dan infrastruktur.

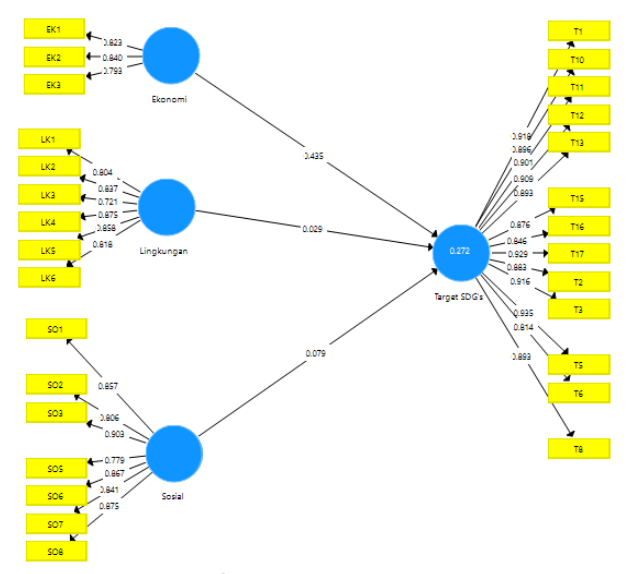

Gambar 3

Sumber. Pengolahan data kuesioner dengan SmartPLS versi 3.2.7, 2018

Untuk dapat memenuhi kriteria convergent validity, maka diperlukan modifikasi terhadap model struktur tersebut dengan menghilangkan indikator yang memiliki nilai loading factor dibawah 0.70 (Ghozali, 2015). Maka tahapan selanjutnya yaitu dengan menghilangkan indikator yang memiliki nilai loading factor dibawah 0.70 yaitu menghilangkan indikator SO2, SO5, SO10, T6, T12, T15, dan T17 dalam model struktural. Kemudian data di running kembali. Setelah data di running kembali menghasilkan nilai indikator lebih dari 0.70 secara keseluruhan seperti Tabel dan Gambar diatas sehingga konstruk atau indikator yang terdapat pada semua variabel tidak adalagi yang harus dieliminasi dari model. Sehingga indikator-indikator pada penelitian valid karena telah memenuhi kriteria convergent validity.

Seperti yang terlihat dalam Tabel diatas semua indikator yang telah dimodifikasi memiliki nilai loading factor diatas 0.70. Semula total keseluruhan indikator adalah 36, namun terdapat tujuh indikator yang tidak valid sehingga total indikator valid adalah 29. Indikator yang memiliki nilai loading factor pada kisaran 0.70-0.79 sebesar $10 \%$, indikator yang memiliki nilai loading factor pada kisaran 0.80-0.89 sebesar $66 \%$, dan indikator yang memiliki nilai loading factor pada kisaran 0.90-1.00 sebesar $24 \%$. Sehingga menunjukan bahwa hasil memiliki tingkat validitas yang cukup tinggi.

Nilai validitas yang cukup tinggi tersebut menandakan bahwa pernyataan yang tersedia pada 29 indikator yang tersisa tersebut memiliki keterkaitan tinggi dengan indikatornya. Sehingga mampu menjawab apakah indikator tersebut dapat mempengaruhi variabelnya dan memiliki pengaruh terhadap variabel lain.

- Discriminant validity dan Average variance exracted (AVE)

Discriminant validity dapat dilakukan dengan melihat nilai cross loading factor untuk mengetahui bahwa konstruk memiliki diskrimanan yang memadai. Dengan cara membandingkan koreksi indikator suatu konstruk tersebut dengan konstruk lainnya. Jika korelasi konstruk memiliki nilai yang lebih tinggi dibandingkan dengan korelasi indikator tersebut terhadap konstruk lain, maka dikatakan konstruk memiliki discriminant validity yang tinggi (Ghozali, 2015). Hasil pengujian discriminant validity dapat diperoleh dengan menggunakan SmartPLS sebagai berikut: 


\begin{tabular}{|l|l|l|l|l|}
\hline & Ekonomi & Lingkungan & Sosial & $\begin{array}{l}\text { Target } \\
\text { SDG's }\end{array}$ \\
\hline EK1 & 0.823 & 0.601 & 0.589 & 0.492 \\
\hline EK2 & 0.840 & 0.771 & 0.639 & 0.399 \\
\hline EK3 & 0.793 & 0.545 & 0.626 & 0.361 \\
\hline LK1 & 0.638 & 0.804 & 0.692 & 0.433 \\
\hline LK2 & 0.660 & 0.837 & 0.748 & 0.328 \\
\hline LK3 & 0.613 & 0.721 & 0.478 & 0.318 \\
\hline LK4 & 0.660 & 0.875 & 0.604 & 0.277 \\
\hline LK5 & 0.689 & 0.858 & 0.715 & 0.294 \\
\hline LK6 & 0.578 & 0.818 & 0.507 & 0.398 \\
\hline SO1 & 0.638 & 0.642 & 0.857 & 0.327 \\
\hline SO2 & 0.593 & 0.645 & 0.806 & 0.291 \\
\hline SO3 & 0.629 & 0.673 & 0.903 & 0.338 \\
\hline SO5 & 0.678 & 0.682 & 0.779 & 0.386 \\
\hline SO6 & 0.703 & 0.666 & 0.867 & 0.317 \\
\hline SO7 & 0.597 & 0.574 & 0.841 & 0.488 \\
\hline SO8 & 0.615 & 0.667 & 0.875 & 0.313 \\
\hline T1 & 0.453 & 0.292 & 0.333 & 0.918 \\
\hline T2 & 0.542 & 0.408 & 0.448 & 0.883 \\
\hline T3 & 0.497 & 0.396 & 0.392 & 0.916 \\
\hline T5 & 0.458 & 0.403 & 0.389 & 0.935 \\
\hline T6 & 0.380 & 0.352 & 0.340 & 0.814 \\
\hline T8 & 0.452 & 0.379 & 0.379 & 0.893 \\
\hline T10 & 0.402 & 0.355 & 0.344 & 0.896 \\
\hline T11 & 0.449 & 0.417 & 0.411 & 0.901 \\
\hline T12 & 0.487 & 0.376 & 0.402 & 0.909 \\
\hline T13 & 0.435 & 0.374 & 0.377 & 0.893 \\
\hline T15 & 0.448 & 0.392 & 0.391 & 0.876 \\
\hline T16 & 0.496 & 0.403 & 0.363 & 0.846 \\
\hline T17 & 0.475 & 0.418 & 0.388 & 0.929 \\
\hline & & Tabel 3 & & \\
\hline
\end{tabular}

Tabel 3

Sumber. Pengolahan data kuesioner dengan SmartPLS versi 3.2.7, 2018

\begin{tabular}{|l|l|l|l|l|}
\hline & $\begin{array}{l}\text { Cronbach's } \\
\text { Alpha }\end{array}$ & rho_A & $\begin{array}{l}\text { Composite } \\
\text { Realibility }\end{array}$ & AVE \\
\hline Ekonomi & 0.758 & 0.771 & 0.859 & 0.671 \\
\hline Lingkungan & 0.903 & 0.912 & 0.925 & 0.673 \\
\hline Sosial & 0.935 & 0.950 & 0.947 & 0.719 \\
\hline $\begin{array}{l}\text { Target } \\
\text { SDG's }\end{array}$ & 0.979 & 0.981 & 0.981 & 0.799 \\
\hline
\end{tabular}

Tabel 4

Sumber. Pengolahan data kuesioner dengan SmartPLS versi 3.2.7, 2018

Pada Tabel diatas dapat dilihat bahwa dari keseluruhan 29 indikator memiliki nilai loading factor tertingggi dibandingkan dengan korelasi loading factor jika dihubungkan dengan variabel lainnya. Hal menunjukan bahwa nilai loading factor pada variabel ekonomi
(EK1, EK2, EK3) memiliki nilai loading factor lebih tinggi dibandingkan dengan variabel lainnya seperti sosial, lingkungan dan target SDGS's.

b. Reliabilitas

Selain uji validitas pengukuran model juga dilakukan untuk menguji reliabilitas suatu konstruk. Uji reliabilitas digunakan untuk menilai akurasi, konsisten dan ketepatan setiap pernyataan untuk menilai indikator. Uji reliabilitas dapat dilakukan dengan melihat nilai Cornbach's Alpha dan Composite Realibility. Jika nilai yang dihasilkan melalui dua uji tersebut telah melebihi nilai 0.70 maka dapat dikatakan bahwa pernyataan pada indikator tersebut memiliki nilai yang reliable. Nilai reliable adalah nilai yang dapat dipercaya,keajegan, konsisten, keandalan, kestabilan pada setiap indikator. Berikut ini adalah analisis mengenai uji reliabilitas pada penelitian ini:

- Cornbach's Alpha

Uji reliabilitas juga dapat diperkuat dengan Cornbach's Alpha. Dengan kriteria nilai yag diharapkan yaitu diatas 0.70 (Ghozali, 2015). Pada Tabel dibawah ini dapat dilihat bahwa variabel ekonomi memiliki nilai 0.758 , lingkungan 0.903 , sosial 0.935, dan target SDG's 0.979. Sehingga dapat disimpulkan bahwa semua konstruk memnuhi kriteria Cornbach's Alpha dan memiliki nilai reliabilitas yang tinggi. Sehingga dapat disimpulkan bahwa hasil pengujian pada setiap indikator dan variabel dapat dipercaya dan konsisten terhadap arah penelitian.

\begin{tabular}{|l|l|l|l|l|}
\hline & $\begin{array}{l}\text { Cronbach's } \\
\text { Alpha }\end{array}$ & rho_A & $\begin{array}{l}\text { Composite } \\
\text { Realibility }\end{array}$ & AVE \\
\hline Ekonomi & 0.758 & 0.771 & 0.859 & 0.671 \\
\hline Lingkungan & 0.903 & 0.912 & 0.925 & 0.673 \\
\hline Sosial & 0.935 & 0.950 & 0.947 & 0.719 \\
\hline Target SDG's & 0.979 & 0.981 & 0.981 & 0.799 \\
\hline
\end{tabular}

Tabel 5

Sumber: Pengolahan data kuesioner dengan SmartPLS versi 3.2.7, 2018

\section{- Composite Realibility}

Hasil pengujian yang dilakukan dengan aplikasi SmartPLS versi 3 mengenai Cornbach's Alpha telah menghasilkan nilai yang reliable untuk menguji apakah penelitian ini benar-benar reliable adalah dengan melihat juga nilai composite reliability jika nilainya melebihi atau diatas 0.70 maka hasil pengujian dalam penelitian ini dapat dipercaya dan memiliki konsistensi 
tinggi (Ghozali, 2015). Pada tabel diatas menyatakan bahwa nilai composite realibility pada setiap variabel memiliki nilai lebih dari 0.70 . Pada variabel ekonomi memiliki nilai 0.859 , pada variabel lingkungan 0.925 , variabel sosial 0.947, dan target SDG's memiliki nilai 0.981 . Nilai untuk setiap variabel telah melampaui 0.70 sehingga dapat disimpulkan bahwa hasil penelitian ini dapat dipercaya dan memiliki konsistensi yang tinggi.

2. Analisis model struktural (inner model)

Analisis model struktural ini dilakukan untuk menguji hubungan antara konstruk laten dengan konstruk endogen. Pada analisis inner model terdapat beberapa analisis yaitu analisis $R$-Square, Effect Size, dan $\mathrm{q}^{2}$. Ada beberapa uji untuk model struktural yaitu sebagai berikut:

- Path Coefficient

Path Coefficient merupakan nilai koefisien jalur, atau besarnya hubungan atau pengaruh antara konstruk laten, jika nilai konstruk laten tersebut memiliki nilai positif maka menandakan bahwa konstruk laten memiliki hubungan positif dengan konstruk endogen, dan jika konstruk laten memiliki niali yang negatif maka konstruk laten memiliki hubungan negatif dengan konsturk endogen (Ghozali, 2015). Nilai Path Coefficient dapat dilihat pada tabel tersebut menunjukan bahwa konstruk Ekonomi, Lingkungan, dan Sosial memiliki nilai positif terhadap konstruk endogen (Target SDG's) dengan nilai $0.435,0.029$, dan 0.079 . sehingga dapat disimpulkan bahwa semua konstruk laten berpengaruh positif terhadap konstruk endogen yaitu Target SDG's.

- $\quad \mathrm{R}$ Square $\left(\mathrm{R}^{2}\right)$

Nilai $R$ Square merupakan koefisien determinasi pada konstruk endogen. Dengan kriteria nilai $R$ Square sebesar 0.67 (kuat), 0.33 (moderat), dan 0.19 (lemah) (Ghozali, 2015). Tabel dibawah ini merupakan hasil estimasi $R$ Square $\left(R^{2}\right)$ dengan menggunakan SmartPLS versi 3.2.7 untuk konstruk endogen yaitu Target SDG's.

\begin{tabular}{|l|l|l|}
\hline & R Square & $\begin{array}{l}\text { R } \\
\text { Adjusted }\end{array}$ \\
\hline Target SDG's & 0.272 & 0.249 \\
\hline
\end{tabular}

Tabel 6

Sumber: Pengolahan data kuesioner dengan SmartPLS versi 3.2.7, 2018

Pada dasarnya penelitian ini memiliki tiga konstruk laten yaitu Ekonomi yang berpengaruh terhadap konstruk endogen yaitu Target SDG's, Sosial yang berpengaruh terhadap konstruk endogen yaitu Target SDG's, dan Lingkungan yang berpengaruh terhadap konstruk endogen yaitu Target SDG's. Pada Tabel diatas menunjukan nilai $R$ Square $\left(R^{2}\right)$ untuk variabel Target SDG's bernilai 0.272 . Hasil ini menunjukan bahwa $27.2 \%$ variabel Target SDG's dipengaruhi oleh variabel Ekonomi, variabel Lingkungan dan variabel Sosial. Hal tersebut memiliki hubungan yang lemah karena memiliki hanya melampaui nilai 0.19 pada batas minimum kriteria $R^{2}$.

Sehingga dapat disimpulkan bahwa hubungan antara variabel ekonomi, sosial dan lingkungan terhadap target SDG's memiliki pengaruh yang sangat rendah. Sehingga target SDG's tersebut secara garis besar tidak dapat tercapai hanya dengan dukungan program $C S R$. Hasil pengujian $R^{2}$ tersebut sesuai dengan teori yang dipaparkan oleh (Ermalena, 2017) pada acara diskusi panel pengendalian tembakau dan tujuan pembang-unan di Indonesia yaitu sebenarnya penca-paian target SDG's tersebut tidak secara keseluruhan tanggungjawab perusahaan atau industri yang beroperasi disuatu daerah tertentu melalui program sosialnya $(C S R)$. Namun untuk mencapai 17 target SDG's tersebut harus melibatkan semua pihak seperti pemerintah, parlemen, media, filantropi \& bisnis, dan pakar \& akademisi. Sehingga untuk mencapai target SDG's pada tahun 2030 melibatkan banyak pihak untuk bekerjasama dan membuat kebijakan untuk mengatasi permasalahan di Indonesia.

Sehingga sebanyak apapun dana yang dikeluarkan oleh perusahaan untuk program CSR tidak mencerminkan bahwa perusahaan telah secara maksimal mempertanggung-jawabkan dampak dari kegiatan operasio-nalnya kepada masyarakat. Dan hal tersebut tidak dapat dijadikan sebagai tolak ukur bahwa dengan adanya program CSR akan berperan secara maksimal untuk pencapaian target SDG's.

- Predictive relevance $\left(q^{2}\right)$ 


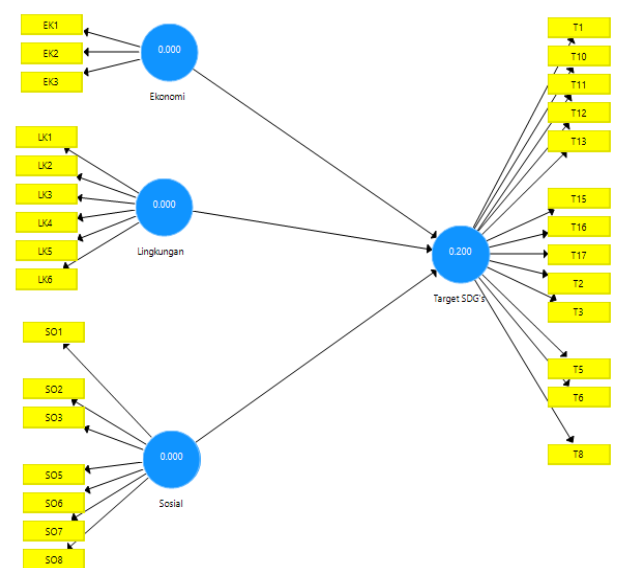

Gambar 4

Sumber: Pengolahan data kuesioner dengan SmartPLS versi 3.2.7, 2018

\begin{tabular}{|l|l|l|l|}
\hline & SSO & SSE & $\begin{array}{l}Q^{2}=1- \\
\text { SSE/SSO })\end{array}$ \\
\hline Ekonomi & 300.0000 & 300.0000 & \\
\hline Lingkungan & 600.0000 & 600.0000 & \\
\hline Sosial & 700.0000 & 700.0000 & \\
\hline $\begin{array}{l}\text { Target } \\
\text { SDG's }\end{array}$ & 1300.0000 & 1.039 .581 & 0.2000 \\
\hline
\end{tabular}

Tabel 7

Sumber. Pengolahan data kuesioner dengan SmartPLS versi 3.2.7, 2018

Tahap berikutnya untuk menguji inner model yaitu dengan melihat predictive relevance $\left(q^{2}\right)$. Uji ini dilakukan untuk mengetahui kapabilitas prediktif dengan prosedur blindfolding dan memiliki kriteria apabila nilai yang didapatkan 0.02 tergolong nilai yang kecil, 0.15 tergolong nilai yang sedang, dan 0.35 tergolong nilai yang tinggi. Uji ini yang dapat dilakukan untuk konstruk endogen dengan variabel reflektif. Hasil pengujian dengan menggunakan SmartPLS ditunjukan oleh Gambar 4 dan Tabel 7 diatas. Nilai $q^{2}$ digunakan untuk melihat pengaruh relatif model struktural terhadap pengukuran observasi untuk variabel tergantung laten.

Gambar dan tabel diatas menunjukan bahwa hasil $q^{2}$ pada variabel endogen yaitu Target SDG's memiliki nilai sebesar 0.200. Hasil tersebut menunjukan bahwa variabel Ekonomi, Sosial, dan Lingkungan memiliki relevansi prediktif yang sedang untuk variabel endogen yaitu Target SDG's dan model struktural tersebut memiliki pengaruh relatif variabel laten ke variabel endogen namun memiliki pengaruh relatif sedang.

\section{Pengujian hipotesa}

Parameter signifikansi yang diestimasi akan memberikan informasi mengenai pengaruh antar variabel penelitian. Dasar yang dapat digunakan dalam menguji hipotesis yaitu dengan melihat output uji hipotesis pada path coefficient dengan menggunakan prosedur bootstrapping.

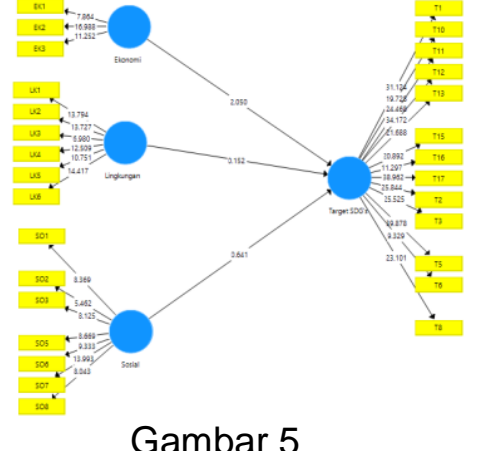

Sumber: Pengolahan data kuesioner dengan SmartPLS versi 3.2.7, 2018

\begin{tabular}{|c|c|c|c|c|c|}
\hline & $\begin{array}{l}\text { Origina } \\
\text { Sample } \\
\text { (O) }\end{array}$ & $\begin{array}{l}\text { Sample } \\
\text { Mean (M) }\end{array}$ & $\begin{array}{l}\text { Standar } \\
\text { Deviation } \\
\text { (STDEV) }\end{array}$ & $\begin{array}{c}T \\
\text { Statistics }\end{array}$ & s $\begin{array}{c}P \\
\text { Value }\end{array}$ \\
\hline $\begin{array}{c}\text { Ekonomi -> } \\
\text { Target } \\
\text { SDG's }\end{array}$ & 0.435 & 0.427 & 0.193 & 2.255 & 0.025 \\
\hline $\begin{array}{c}\text { Lingkungan } \\
\text {-> Target } \\
\text { SDG's }\end{array}$ & 0.029 & 0.040 & 0.172 & 0.169 & 0.866 \\
\hline $\begin{array}{c}\text { Sosial -> } \\
\text { Target } \\
\text { SDG's }\end{array}$ & 0.079 & 0.118 & 0.118 & 0.673 & 0.501 \\
\hline
\end{tabular}

Sumber: Pengolahan data kuesioner dengan SmartPLS versi 3.2.7, 2018

Pada Partial Least Square (PLS), pengujian secara statistik setiap pengaruh yang dihipotesiskan dilakukan dengan menggunakan simulasi. Untuk hal ini dilakukan dengan SmartPLS versi 3.2.7 dengan prosedur bootstrapping terhadap sampel. Pnegujian yang dilakukan dengan bootstrapping juga berguna dalam meminimalkan masalah ketidaknormalan data penelitian. Ukuran signifikan pada hipotesis dapat menggunakan cara membandingkan antara nilai t-table dan tstatistic. Pada penelitian ini menggunakan tingkat keyakinan adalah 95\% (alpha 5\%). Jika t-statistic lebih tinggi dibandingkan dengan nilai t-table (1.96) berarti hipotesis tersebut diterima. Hasil pengujian 
bootstrapping dengan analisis PLS yaitu sebagai berikut:

1. Pengaruh $C S R$ bidang ekonomi terhadap pencapaian target SDG'S

Tabel 8 hasil pengujian
bootstrapping menunjukan bahwa hubungan variabel $C S R$ bidang ekonomi dengan pencapaian target SDG's menunjukan original sample sebesar 0.435. Besarnya koefisien parameter 0.435 yang berarti terdapat pengaruh positif CSR bidang ekonomi terhadap pencapaian target SDG's. Semakin tinggi presepsi kepuasan responden terhadap manfaat dari kegiatan CSR bidang ekonomi, maka semakin besar potensi pencapaian target SDG's. Pengaruh positif antara variabel $C S R$ bidang ekonomi terhadap target $S D G$ 's karena secara keseluruhan indikator pada variabel ekonomi memiliki nilai convergent validi lebih dari 0.70 , nilai tersebut menggambarkan bahwa indikator kinerja ekonomi, keberadaan pasar, dan dampak ekonomi tidak langsung telah memiliki program CSR yang telah dirasakan oleh masyarakat dan berdampak langsung pada perekonomian masyarakat.

\section{Selanjutnya jika dilihat pada tabel 8 hasil pengujian bootstrapping} menunjukan bahwa hubungan variabel $C S R$ bidang ekonomi dengan pencapaian target SDG's pada kolom t statistic tersebut menyatakan angka 2.255. Tstatistic variabel bidang ekonomi lebih tinggi dibandingkan dengan nilai t-table yaitu $2.255>1.96$, maka nilai tersebut menandakan bahwa variabel bidang ekonomi berpengaruh signifikan terhadap variabel target SDG's. Pengaruh signifikan tersebut menandakan bahwa program CSR Holcim pada bidang ekonomi telah mampu sedikit menyelesaikan permasalahan ekonomi pada masyarakat.

Permasalahan pertama yang telah sedikit teratasi adalah kemiskinan pada Kabupaten Cilacap, garis kemiskinan (dalam rupiah) Kabupaten Cilacap pada tahun 2017 lebih rendah dibandingkan dengan nilai nasional garis kemiskinan Provinsi Jawa Tengah. Nilai nasional garis kemiskinan di Provinsi Jawa Tengah yaitu sebesar $\mathrm{Rp} 333.224$ sedangkan garis kemiskinan di Kabupaten Cilacap sebesar Rp 307.041 (BPS Jawatengah, 2018). Dapat disimpulkan bahwa variabel CSR bidang ekonomi berpengaruh terhadap variabel target SDG's. Berpengaruhnya variabel CSR bidang ekonomi karena program CSR yang telah diimplementasikan PT Holcim Indonsia Tbk pada masyarakat telah mampu membantu masyarakat dalam menyelesaikan permasalahan finansial. Pada setiap indikator CSR bidang ekonomi memiliki program-program yang mampu menyelesaikan permasalahan disetipap indikatornya.

Program CSR untuk indikator kinerja ekonomi yang dijalankan oleh perusahaan bertujuan untuk membantu permasalahan finansial masyarakat. Program CSR Holcim yang termasuk ke dalam kriteria indikator kinerja ekonomi adalah microfinance. Microfinance merupakan program pemberian modal kepada UMKM dikarenakan seringkali UMKM sangat sulit untuk mendapatkan kredit atau pinjaman modal dari instansi perbankan. Dengan adanya program microfinance tersebut masyarakat mampu menjalankan usahanya untuk mendapatkan penghasilan masyarakat. Program CSR yang kedua adalah Posdaya, program tersebut telah memberikan penyuluhan dan pelatihan kepada masyarakat untuk mengolah sumber daya yang tersedia menjadi salah satu produk khas dari daerah tersebut. Setelah produk tersebut siap dijual, masyarakat menitipkannya pada toko oleh-oleh atau pada toko panginyongan. Sehingga masyarakat mampu memiliki penghasilan.

Indikator kedua pada variabel CSR bidang ekonomi adalah keberadaan pasar. Masyarakat merasakan dengan adanya suatu industri beroperasi pada daerah pemukimannya, mampu memberikan kesempatan bekerja bagi masyarakat yang belum memiliki pekerjaan atau pengangguran dan memberikan upah sesuai dengan standar upah minimum regional daerah. Melalui program EnterpriseBased Vocational Education (EVE) PT Holcim Indonesia Tbk banyak mempekerjakan masyarakat lokal pada industrinya. Hal tersebut terjadi karena program EVE tersebut merupakan program pendidikan keahlian pada industri semen yang diberikan oleh PT Holcim Indonesia Tbk untuk masyarakat, setiap masyarakat 
yang mendapatkan pendidikan program EVE tersebut dan memiliki kompetensi yang baik akan bekerja di Holcim, namun jika tidak berkesempata untuk bekerja di PT Holcim Indonesia Tbk masyarakat tersebut akan mendapatkan pekerjaan di perusahaan lain.

Indikator terakhir pada variabel $C S R$ bidang ekonomi adalah dampak ekonomi tidak langsung. Program CSR tersebut adalah pembangunan infrastruktur umum seperti pelebaran akses antar desa atau antar daerah. Dengan program pembangunan jalan atau pelebaran jalan tersebut membantu masyarakat memasarkan barang dagangnya atau mempermudah masyarakat untuk mencari mata pencaharian. Realisasi program tersebut digamabrkan pada Gambar 4.9. Sehingga secara tidak lansgung pembangunan infrastruktur tersebut mampu meningkatkan perekonomian masyarakat.

Sehingga disimpulkan bahwa hipotesis pertama pada penelitian ini diterima dan menggambarkan bahwa adanya pengaruh antara $C S R$ bidang ekonomi terhadap target SDG's. Hasil analisa dan pengujian tersebut sesuai dengan penelitian (Novita \& Iriani, 2016) yang menyatakan bahwa karena adanya Posdaya sebagai salah satu program CSR Holcim mampu meningkatkan kemandirian ekonomi masyarakat dengan memberikan kegiatan-kegiatan yang mampu meningkatkan keahlian masyarakat. Peningkatan keahlian masyarakat tersebut mampu menghasilkan produk yang dapat dijual dan mendapatkan penghasilan. Sehingga mampu meningkatkan kesejahteraan masyarakat bidang ekonomi.

\section{Pengaruh CSR bidang sosial terhadap pencapaian target SDG's.}

Hasil pengujian hipotesis dua menunjukan bahwa hubungan variabel CSR bidang sosial dengan pencapaian target SDG's menunjukan original sample sebesar 0.079. Besarnya koefisien parameter 0.079 yang berarti terdapat pengaruh positif CSR bidang sosial terhadap pencapaian target SDG's. Semakin tinggi presepsi kepuasan responden terhadap manfaat dari kegiatan CSR bidang sosial, maka semakin besar potensi pencapaian target $S D G$ 's. Keadaan tersebut menunjukan bahwa program CSR bidang sosial memiliki hubungan positif terhadap pencapaian target SDG's. Hubungan positif positif tersebut menggam-barkan bahwa secara keseluruhan indi-kator pada variabel tersebut memiliki pengaruh kepada variabel target SDG's. Namun nilai original sample tersebut sangatlah kecil 2,9\%. Sehingga sepuluh indikator pada variabel sosial tidak secara maksimal berpengaruh terhadap target SDG's dan menghasilkan tidak signifikannya hipotesis CSR bidang sosial berpengaruh terhadap pencapaian target SDG's.

Selanjutna jika dilihat dari hasil pengujian hipotesis menunjukan nilai tstatistic kurang dari 1,96 , pada kolom tstatistic tersebut menyatakan angka 0.169 . Nilai tersebut lebih rendah dibandingkan dengan nilai t-table yaitu $0.169<1.96$ menandakan bahwa tidak signifikannya pengaruh antara variabel bidang sosial dengan variabel target SDG's karena program CSR Holcim yang diimplementasikan pada bidang sosial tidak bertujuan untuk memperbaiki permasalahan masyarakat pada bidang sosial. Dari beberapa program yang diimplementasikan Holcim, tujuan akhirnya lebih menunjang kearah ekonomi saja, untuk bidang sosialnya tidak secara spesifik. Sehingga sepuluh indikator pada variabel sosial tidak secara maksimal berpengaruh terhadap target SDG's dan menghasilkan tidak signifikannya hipotesis CSR bidang sosial berpengaruh terhadap pencapaian target $S D G$ 's. Sepuluh indikator tersebut adalah kepegawaian, kesehatan dan kesela-matan kerja, pelatihan dan pendidikan, kesetaraan dan remunerasi perempuan dan laki-laki, hak adat, pekerja anak, assesmen, masyarakat lokal, anti korupsi, dan mekanisme pengaduan dampak terhadap masyarakat. Terdapat tiga indikator yang menyebabkan variabel $C S R$ bidang sosial tidak berpengaruh terhadap target SDG's. Fenomena tersebut terjadi karena indikator tersebut memiliki nilai validitas kurang dari 0.70 .

Ketiga indikator yang tidak valid tersebut yang harus dikeluarkan dari pengujian-pengujian selanjutnya, yang menyebabkan tidak signifikannya pengaruh variabel $C S R$ bidang sosial terhadap 
pencapaian target SDG's. Faktor lain yang menyebabkan variabel CSR bidang sosial tidak beperngaruh signifikan terhadap target SDG's adalah salah satu target SDG's yang masuk kedalam kategori sosial yaitu perdamaian, keadilan, dan kelembagaan yang tangguh memiliki nilai convergent validity kurang dari 0.70 sehingga dinyatakan tidak valid. Tidak validnya indikator tersebut menyebabkan harus di droped outnya indikator tersebut pada penelitian.

Tiga indikator pada variabel $C S R$ bidang sosial harus dikeluarkan dari pengujian karena memiliki nilai convergent validity kurang dari 0.70 , sehingga dinyatakan tidak valid. Tiga indiktor tersebut adalah kesetaraan remunerasi perempuan dan laki-laki, anti korupsi, dan mekanisme pengaduan dampak terhadap masyarakat. Faktor yang menyebabkan bahwa ketiga indikator tidak valid adalah masyarakat tidak merasakan program CSR yang menggambarkan ketiga indikator tersebut, sehingga untuk menjawab pernyataan yang tersedia pada kuesioner masyarakat kurang memahaminya. Tingkat pemahaman yang minim pada masyarakat menyebabkan jawaban yang diberikan tidak sesuai dengan ketentuan penelitian, sehingga pernyataan tersebut tidak mampu menilai dan menggambarkan indikatornya.

Pernyataan yang digunakan untuk menilai indikator kesetaraan remunerasi perempuan dan laki-laki (SO4) adalah perusahaan rutin memberikan pelatihan keterampilan untuk meningkatkan kompetensi masyarakat tidak mampu menggambarkan apakah program CSR Holcim telah memenuhi kriteria kesetaraan remunerasi perempuan dan laki-laki. Secara garis besar pernyataan tersebut hanya dapat mengambarkan bahwa kemampuan masyarakat meningkat karena adanya pelatihan tersebut, walaupun maksud dari pernyataan tersebut adalah dengan meningkatnya kemampuan masyarakat tersebut mampu menyetarakan kaum lakilaki dan perempuan pada kehidupan sehari-hari. Namun hal tersebut belum mampu menggambarkan bahwa perempuan dan laki-laki mendapatkan hak yang sama. Hal tersebut terjadi karena PT Holcim Indonesia Tbk belum memiliki program CSR yang mampu menyelesaikan permasalahan perbedaan hak antara laki-laki dan perempuan pada segi pekerjaan, pendidikan, bahkan hak-hak yang lainnya.

Indikator kedua yang tidak valid sesuai dengan hasil pengujian pada SmartPLS adalah indikator anti-korupsi (SO9) pernyataan yang digunakan untuk menilai adalah perusahaan menyelenggarakan forum komunikasi masyarakat secara rutin sebagai media informasi dan diskusi program dan inisiatif program CSR tidak mampu menggambarkan apakah program CSR Holcim telah memenuhi kriteria pada indikator tersebut. Indikator anti-korupsi tersebut digunakan untuk mengetahui apakah salah program CSR Holcim mampu mengindikasikan risiko operasional yang terkait dengan korupsi. Namun dengan adanya forum komunikasi masyarakat tersebut tidak dapat mengindikasi risiko operasional perusahaan melalui program CSR, sehingga pernyataan tersebut tidak mampu menggambarkan indikator tersebut dan tidak ada program CSR Holcim yang secara khusus dibuat untuk menyelesaikan permasalahan mengenai korupsi tersebut. Sehingga indikator anti korupsi menghasilkan nilai convergent validity yang tidak valid.

Mekanisme pengaduan dampak terhadap masyarakat (SO10) merupakan indikator ketiga yang tidak valid. Pernyataan yang digunakan untuk menilai adalah perusahaan menyelenggarakan forum komunikasi masyarakat secara rutin sebagai media informasi dan diskusi program dan inisiatif program CSR tidak mampu menggambarkan apakah program CSR Holcim telah memenuhi kriteria pada indikator tersebut. Pada realisasinya forum komunikasi masyarakat tersebut dibentuk untuk momen atau acara masyarakat menyampaikan aspirasinya. Namun sebenarnya tidak hanya melalui FKM tersebut masyarakat menyampaikan aspirasinya namun ada beberapa alternatif, salah satunya adalah melalui costumer relationship officer (CRO). Sehingga pernyataan tersebut tidak sepenuhnya menjadi alat ukur untuk indikator mekanisme pengaduan dampak terhadap masyarakat.

Sehingga disimpulkan bahwa hipotesis kedua pada penelitian ini ditolak 
dan menggambarkan bahwa tidak berpengaruhnya antara CSR bidang sosial terhadap target SDG's. Hasil tersebut bertolak belakang dengan penelitian yang dilakukan oleh (Theresia, 2018) yang menunjukan bahwa terdapat enam kriteria yang diungkapkan dalam laporan keberlanjutan dari tujuhbelas kriteria oleh perusahaan yang tergabung pada IGCN. Pengungkapan yang dominan lebih ke arah sosial daripada lingkungan seperti kesehatan dan kesejahteraan, pendidikan, air bersih dan sanitasi, konsumen dan kemitraan. Sehingga hasil penelitian ini dapat dijadikan pemetaan pengungkapan yang dominan dan kurang diungkapkan sehingga dapat meningkatkan motivasi pengungkapan CSR yang memenuhi kriteria SDG's.

Perbedaan hasil penelitian
tersebut dikarenakan pada setiap perusahaan beroperasi diwilayah atau lokasi yang berbeda dengan permasalahan yang berbeda pula. Tidak hanya itu program CSR Holcim yang telah diimplementasikan pada masyarakat hanya berfokus pada permasalahan perekonomian Kabupaten Cilacap saja, karena dampak akhir dari semua program hanya membuat perbaikan pada perekonomian masyarakat. Program tersebut adalah Integrated farming, Chicken farming, Posdaya, Micro enterprise - retail mobility, Microfinance, Community based waste management, Practical ideas, empowering women dan Cooking up some value, Infrastruktur, dan Education.

Program integrated farming, chicken farming, posdaya, micro enterprise - retail mobility, microfinance, community based waste management, practical ideas, empowering women dan cooking up some value, infrastruktur, dan education memberikan dampak yang sangat besar terhadap perekonomian masyarakat. Dua dari sepuluh program termasuk dalam program yang mampu menyelesaikan permasalahan sosial. Dua program tersebut adalah infrastruktur dan education, namun kedua program tersebut juga mampu menyelesaikan permasalahan pada bidang ekonomi karena dengan adanya pendidikan masyarakat mampu mendapatkan pekerjaan yang layak dan mendapatkan penghasilan dan pembangunan infrastruktur dalam program CSR dalam bentuk pelebaran jalan yang membantu akomodasi perdagangan.

3. Pengaruh CSR bidang lingkungan terhadap pencapaian target SDG's.

Hasil pengujian hipotesis dua menunjukan bahwa hubungan variabel $C S R$ bidang lingkungan dengan pencapaian target SDG's menunjukan original sample sebesar 0.029. Besarnya koefisien parameter 0.029 yang berarti terdapat pengaruh positif $C S R$ bidang lingkungan terhadap pencapaian target $S D G$ 's. Semakin tinggi presepsi kepuasan responden terhadap manfaat dari kegiatan CSR bidang lingkungan, maka semakin besar potensi pencapaian target SDG's.

Selanjutnya jika dilihat dari t-statistic kurang dari 1,96. Pada kolom t-statistic hasil pengujian bootstraping tersebut menyatakan angka 0.673. Nilai tersebut lebih rendah dibandingkan dengan nilai t-table yaitu $0.673<1.96$, hal tersebut menandakan bahwa variabel bidang lingkungan tidak berpengaruh terhadap variabel target $S D G$ 's. Faktor utama tidak berpengaruhnya program CSR bidang lingkungan tidak berpengaruh terhadap pencapaian target SDG's adalah program yang diimplementasikan Holcim untuk mempertanggungjawabkan dampak lingkungan dari kegiatan operasinya tidak termasuk pada program CSR. Program tersebut hanya dijalankan oleh perusahaan tanpa melibatkan peran serta masyarakat untuk melestarikan lingkungan. Sehingga pengujian hipotesis untuk hipotesis yang ketiga menghasilkan tidak signifikannya pengaruh antara variabel bidang lingkungan dengan variabel target SDG's.

Namun pada variabel target SDG's terdapat tiga indikator yang termasuk dalam bidang lingkungan yang memiliki nilai convergent validity kurang dari 0,70. Sehingga ketiga indikator tersebut harus dikeluarkan dari pengujian penelitian. Indikator tersebut adalah kehidupan sehat dan sejahtera, energi bersih dan terjangkau, dan berkurangnya kesenjangan. Indikator kehidupan sehat dan sejahtera merupakan indikator yang tidak valid, kerana pernyataan yang digunakan untuk menilai tidak mampu menggambarkan apakah program CSR Holcim telah memenuhi 
kriteria pada indikator tersebut. Keadaan tersebut terjadi karena pernyataan pertama pada indikator ini tidak memiliki standar pengukuran yang jelas, karen cara hidup sehat dapat dinilai dari beberapa aspek seperti rutin memeriksakan kehamilan, imuniasasi, dan lain-lain. Sehingga pernyataan tersebut tidak dapat menilai indikator kehidupan sehat dan sejahtera. Faktor kedua karena tidak ada program CSR yang secara khusus dibentuk untuk menyelesaikan permasalahan tersebut.

Selanjutnya untuk indikator energi bersih dan terjangkau sama dengan indikator sebelumnya, tidak validnya indikator tersebut karena belum ada program CSR yang secara khusus dibentuk untuk menyelesaikan permasalah tersebut. Indikator terakhir adalah penanganan perubahan iklim karena pernyataan yang digunakan untuk menilai kurang mampu menilai indikator tersebut. Pernyataan tersebut adalah masyarakat lebih memperhatikan cara hidup sehat. Maksud penelitian menggunakan pernyataan tersebut pada indikator penanganan perubahan iklim adalah dengan adanya program CSR diharapkan masyarakat mampu menyesuaikan diri pada saat perubahan musim. Penyesuaian diri masyarakat tersebut dapat digambarkan melalui tidak terganggunya kesehatan, tidak terhambatnya kegiatan sehari-hari dan tidak hilangnya matapencaharian. Namun pernyataan yang digunakan pada indikator penanganan perubahan iklim tidak mampu mencangkup beberapa kriteria yang telah dijelaskan sebelumnya.

Hasil pengujian hipotesis ketiga dengan menggunakan bootstrapping calculation tersebut sesuai dengan paparan yang diberikan oleh (Ermalena, 2017) pada acara diskusi panel pengendalian tembakau dan tujuan pembangunan di Indonesia yaitu sebenarnya pencapaian target SDG's tersebut tidak secara keseluruhan tanggungjawab perusahaan atau industri yang beroperasi disuatu daerah tertentu melalui program sosialnya (CSR). Namun untuk mencapai 17 target SDG's tersebut harus melibatkan semua pihak seperti pemerintah, parlemen, media, filantropi \& bisnis, dan pakar \& akademisi.
Berdasarkan pokok arahan presiden dalam sidang kabinet tanggal 23 Desember 2016 menyatakan bahwa target SDG's tersebut dapat tercapai bila mampu mengoptimalkan peran koordinasi KemenPPN/ Bappenas dalam pembangunan, karena hampir seluruh tujuan pembangunan berkelanjutan telah terakomodasi dalam RPJMN dan setiap kelembagaan yang ada dapat lansgung bekerja, baik secara starategis maupun operasional.

Bahkan hasil pengujian hipotesis tersebut sesuai dengan hasil penelitian (Theresia, 2018) yang menyatakan bahwa pengungkapan program CSR perusahaan yang tergabung dalam Indonesia Global Compact Network (IGCW) jika ditinjau dari 17 tujuan SDG's hasil analisa hanya enam yang mampu diungkapkan dan diimplementasikan pada masyarakat. Enam tujuan yang telah diungkapkan dan diimplementasikan tersebut lebih dominan pada arah sosial seperti kesehatan dan kesejahteraan, pendidikan, air bersih dan sanitasi, konsumen dan kemitraan, sehingga 11 tujuan yang belum diungkapkan pada laporan keberlanjutan perusahan, menandakan bahwa program CSR perusahaan tersebut belum dapat membantu untuk mencapai target SDG's pada tahun 2030.

Faktor yang menyebabkan 17 tujuan SDG's tersebut tidak dapat diungkapkan adalah karena pengungkapan dan implementasi program CSR sebenarnya dilakukan perusahaan sesuai dengan kebutuhan masyarakat. Pada kejadian yang sebenarnya PT Holcim Indonesia Tbk membuat kegiatan social pada masyarakat sesuai dengan rekomendasi masyarakat, kegiatan tersebut bukan bersumber dari manajemen Holcim (Novita \& Iriani, 2016). Pada penelitian (Aras, 2008) menghasilkan kesimpulan bahwa setiap hipotesis tidak valid karena faktor pengungkapan dan implementasi program $C S R$ akan lebih jelas dan memadai seiring berjalannya waktu.

Sehingga dapat disimpulkan bahwa hasil penelitian ini lebih dominan pengungkapan program CSRnya mengarah pada sektor ekonomi. Karena semua program CSR yang telah diimplementasikan oleh Holcim semua programnya berdampak pada perbaikan perekonomian masyarakat sesuai dengan penelitian (Novita \& Iriani, 
2016). Hasil analisis menyatakan bahwa PT Holcim Indonesia Tbk dalam implementasi CSR hanya mampu mendukung tercapainya target SDG's pada bidang ekonomi saja dan pada variabel lingkungan dan sosial tidak dapat mendukung tercapainya target SDG's.

\section{KESIMPULAN}

Simpulan yang dapat dipaparkan berdasarkan hasil analisis data tentang "Implementasi Program CSR Terhadap Pencapaian Target SDG's (Studi Kasus Masyarakat Kabupaten Cilacap yang Merasakan Program CSR Holcim Cilacap)" adalah kegiatan CSR bidang ekonomi berpengaruh terhadap pencapaian target $S D G$ 's, sedangkan $C S R$ bidang sosial dan lingkungan tidak berpengaruh terhadap target SDG's. Faktor yang menyebabkan hasil penelitian tersebut adalah :

1. Implementasi program CSR suatu perusahaan terbatas hanya pada wilayah yang berada pada sekitar perusahaan. Contohnya PT Holcim Indonesia Tbk hanya mengimplementasikan program CSRnya hanya pada Kecamatan

\section{IMPLIKASI DAN KETERBATASAN}

\section{Implimkasi}

Hasil penelitian ini digunakan sebagai perbaikan untuk setiap perusahaan untuk bertanggungjawab kepada masyarakat dan lingkungan atas dampak kegiatan operasionalnya. Sehingga target sasaran program CSR tersebut sesuai dengan keadaan yang sebenarnya pada masyarakat. Tidak hanya masyarakat yang bertempat tinggal disekitar perusahaan yang mendapatkan bantuan sosial tersebut, namun masyarakat yang terkena dampak dari kegiatan operasionalnya. Dan lebih mengembangkan program CSR tersebut kearah pencapaian pada bidang sosial dan lingkungan.

\section{Keterbatasan}

Cilacap Tengah, Cilacap Selatan, Cilacap Utara, dan Jeruk Legi dari total keseluruhan 24 Kecamatan yang terdapat pada Kabupaten Cilacap.

2. Keberadaan industri besar di Kabupaten Cilacap berpusat pada jantung kota sehingga wilayah yang terkena dampak program CSR yang berada pada sekitar industri. Sehingga tanggapan responden yang telah dipaparkan pada bab sebelumnya (hanya bersumber dari masyarakat Kecamatan Cilacap Tengah, Cilacap Selatan, Cilacap Utara, dan Jeruk Legi.

3. Program CSR yang telah diimplementasikan pada masyarakat secara garis besar hanya mampu menyelesaikan permasalah ekonomi pada masyarakt. Hal tersebut dapat dilihat dari hasil pengujian dan analisa hipotesis pada bab pembahasan. Menurut argumen manajemen Holcim secara indikator pencapaian target $S D G$ 's telah dijalankan oleh perusahaan secara keseluruhan, namun tidak menjadi rencana program $C S R$ yang diimplementasikan secara keberlanjutan pada masyarakat. Fokus program CSR PT Holcim Indonesia Tbk pada indikator ekonomi saja, sehingga indikator sosial dan lingkungan terabaikan.

Penelitian ini telah sesuai dengan prosedur ilmiah, namun terdapat bebe-rapa keterbatasan pada penelitian ini yaitu :

1. Hanya melakukan penelitian pada satu wilayah yang digunakan PT Holcim Indonesia Tbk sebagai lokasi industri.

\section{REFERENCES}

Abdullah, O. s. (2016). Pembangunan

Berkelanjutan di Indonesia. Surabaya: Gramedia.

Aprilia, K., \& Ghozali, I. (2015). Teknik Penyusunan Skala Likert. Semarang: Futama.

Aras, G. (2008). Governance and Sustainibility an investigation Into the relationship between corporate sustainibility. Management Decision, 46. 
Budimanta, A., Prasetijo, A., \& Rudito, B. (2007). Corporate Social Responsibility (Second Edi). Jakarta.

Dewan Standar Akuntan Keuangan Ikatan Akuntan Indonesia (IAI). 2012. Standar Akuntansi Keuangan. Jakarta: Ikatan Akuntan Indonesia.

Dwijatenaya, I. B. M. A. (2017). Corporate Social Responsibility (CSR): Empowering Program For Farmers' Welfare. International Journal of Economic, Commerce and Management, $V$.

Farida, N. (2014). Analisa Pengaruh Implementasi CSR Terhadap Kesejahteraan Sosial di BMT Harapan Umat Kudus, Vol 7 No 1.

Febrianto, R. (2014). Analisa Penerapan Corporate Social Responsibility Pada PT Pertamina Bagi Pengembangan Masyarakat.

Ferdinand, A. (2014). Metode Penelitian Manajemen (5th ed.). Semarang: Seri pustaka kunci 12.

Freeman, E. (2004). Manajemen.

Ghozali, I., \& Latah, H. (2012). Partial Least Squares (2nd ed.). Semarang.

Harahap, S. S. (2009). Analisa Kritis Atas Laporan Keuangan.

Haryono, J. (2018). E-JRA Vol. 07 No. 09 Agustus 2018 Fakultas Ekonomi dan Bisnis Universitas Islam Malang. EJRA, 07(09), 51-64.

Iriantara, Y. (2007). Community Relations. Jakarta: Simbiosa Rekatama Media.

Lako, Andreas. 2011. Dekonstruksi CSR \& Reformasi Paradigma Bisnis Dan Akuntansi. Jakarta. Erlangga.

Lukmansyah, O. (2018). Empat hal di balik angka kemiskinan Indonesia yang disebut mencatat "sejarah."

Mapisangka, A. (2009). Implementasi CSR terhadap Kesejahteraan Hidup
Masyarakat. Jesp, 1(1). https://doi.org/10.1016/J.BIOLOGICAL S.2017.01.007

Najiyanti, S., Asmana, A., \& Suryadiputra, I. N. N. (2005). Pemberdayaan Masyarakat. Bogor: Wetlands International.

Novita, \& Iriani, F. (2016). Dampak Pelaksanaan Program Corporate Social Responsibility (CSR) PT Holcim Indonesia Tbk Terhadap Masyarakat Lokal Di Kabupaten Cilacap . Jurnal Kesejahteraan Sosial Maret 2016 Vol. 3 No. 1, Maret 2016: 27-38 ISSN:23549874, 3(1), 27-38.

PBB. (2017). Sustainable Development Goals. Bandung.

Saidi, Z., \& Abidin, H. (2004). Menjadi Bangsa Pemurah: Wacana dan Praktek Kedermawanan Sosial di Indonesia. Jakarta: Piramedia.

Sekaran, U., \& Baugie, R. (2016). Research Methods for Business (Seventh). United kingdom: Wiley.

Standard, G. (2018). GRI STANDARDS GLOSSARY.

Sugiyono. (2017). Metode Penelitian kuantitatif, kualitatif dan $R \& D$. Bandung: Alfabeta.

Suharto, E. (2009). Pekerjaan Sosial di Dunia Industri, Memperkuat CSR (Corporate Social Responsibility). (Alfabeta, Ed.). Bandung.

Theresia. (2018). Analisis Penerapan Sustainibility Development Goals (SDGs) Pada Beberapa Anggota Indonesia Global Compact Network (IGCN). National Conference of Creative Industry, (September), 5-6.

Undang-Undang Nomor 40 Tahun 2007 Tentang Perseroan Terbatas

Untung, H. Budi. 2008. Corporate Social Responsibility. Jakarta. Sinar Grafika. Wibosono, Y. (2007). Membedah Konsep \& Aplikasi CSR 